\title{
An unusual cause of thunderclap headache after eating the hottest pepper in the world - "The Carolina Reaper"
}

\author{
Satish Kumar Boddhula, ${ }^{1}$ Sowmya Boddhula, ${ }^{2}$ Kulothungan Gunasekaran, ${ }^{3}$ \\ Edward Bischof ${ }^{2}$
}

IInternal Medicine, Bassett Medical Center, Cooperstown, New York, USA

${ }^{2}$ Bassett Medical Center, Cooperstown, New York, USA ${ }^{3}$ Henry Ford Health System, Detroit, Michigan, USA

\section{Correspondence to} Dr Kulothungan Gunasekaran, stankuloth@gmail.com

Accepted 28 February 2018

\section{DESCRIPTION}

A 34-year-old man with no significant medical history presented to the emergency room (ER) after an episode of thunderclap headache. His symptoms began with dry heaves but no vomiting immediately after participation in a hot pepper contest where he ate one 'Carolina Reaper,' the hottest chili pepper in the world. He then developed intense neck and occipital head pain that became holocephalic. During the next few days, on at least two occasions and in retrospect he thought probably more often, he experienced brief intense thunderclap headaches lasting seconds. The pain was excruciating and thus he came to the ER. He denied any focal tingling sensation or weakness, slurred speech, or transient loss of vision. Physical examination revealed blood pressure of $134 / 69 \mathrm{~mm} \mathrm{Hg}$ and no neurological deficits. Urine drug screen and non-contrast CT head and neck were unremarkable. CT angiography revealed no aneurysm but demonstrated unexpected multifocal luminal narrowing in the left supraclinoid internal carotid artery, M1 segment of bilateral middle cerebral arteries, and P1 segments of bilateral posterior cerebral arteries consistent with vasospasm (figure 1A). A presumptive diagnosis of thunderclap headache secondary to reversible cerebral vasoconstriction syndrome (RCVS) was made based on the clinical presentation of a severe acute headache, exclusion of aneurysmal subarachnoid haemorrhage, and segmental cerebral arterial vasoconstriction on CT angiography. Our patient's symptoms improved

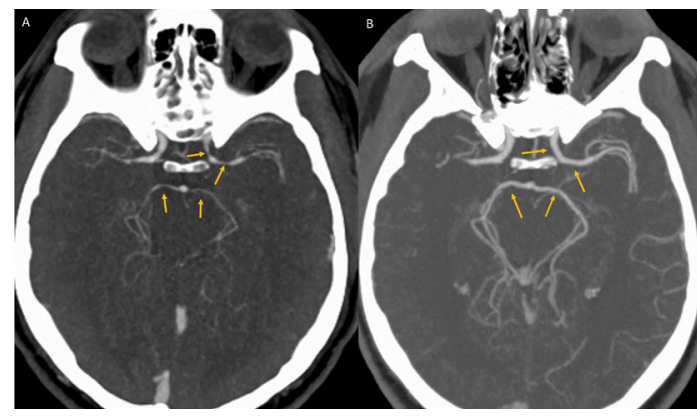

Figure 1 (A) CT angiography showing unexpected luminal narrowing in the left supraclinoid internal carotid artery, M1 segment of bilateral middle cerebral arteries, and P1 segments of bilateral posterior cerebral arteries consistent with vasospasm. (B) CT angiography showing resolution of luminal narrowing after 5 weeks of supportive care.

\section{Learning points}

RCVS should be considered as a potential cause of thunderclap headache after most common causes are ruled out including subarachnoid haemorrhage, cerebral vein thrombosis, cervical artery dissection, etc.

- RCVS should be considered in the differential diagnosis in patients who present with thunderclap headache after ingestion of cayenne pepper, which is a vasoactive substance.

- The primary treatment for RCVS is removal of the offending agent and supportive care.

with supportive care, he had no further thunderclap headaches, and repeat CT angiography 5 weeks later demonstrated resolution of luminal narrowing consistent with RCVS (figure 1B).

RCVS is characterised by multifocal cerebral arterial constriction that resolves within days to weeks and often presents with a thunderclap headache. It can occur without an identifiable cause, as an idiosyncratic reaction to certain medications (ergotamine, selective serotonin reuptake inhibitors, alphasympathomimetic decongestants, and triptans), or secondary to an illicit drug (cocaine, amphetamines, and ecstasy). ${ }^{1}$ No cases of RCVS secondary to peppers or cayenne have been previously reported, but ingestion of cayenne pepper has been associated with coronary vasospasm and acute myocardial infarction. ${ }^{2}$ Given the development of symptoms immediately after exposure to a known vasoactive substance, it is plausible that our patient had RCVS secondary to the 'Carolina Reaper.' Treatment is observation and removal of the offending agent. Calcium channel blockers are widely used but there is no evidence that they improve outcome or are superior to symptomatic treatment alone.

Acknowledgements The authors would like to thank Salil Sharma and Gregory Cummings for their help with images and clinical care. We would also like to thank Sarah Whiteshouse for language editing.

Contributors SKB was responsible for data acquisition, analysis, interpretation and manuscript preparation. SB participated in manuscript preparation and edition. GK participated in data interpretation, manuscript preparation and evaluation. EB supervised development of the manuscript and final evaluation. All authors read and approved the final version of the manuscript. 


\section{Images in...}

Funding The authors have not declared a specific grant for this research from any funding agency in the public, commercial or not-for-profit sectors.

Competing interests None declared.

\section{Patient consent Obtained.}

Provenance and peer review Not commissioned; externally peer reviewed.

(c) BMJ Publishing Group Ltd (unless otherwise stated in the text of the article) 2018. All rights reserved. No commercial use is permitted unless otherwise expressly granted.

\section{REFERENCES}

1 Calabrese LH, Dodick DW, Schwedt TJ, et al. Narrative review: reversible cerebral vasoconstriction syndromes. Ann Intern Med 2007;146:34.

2 Sogut $\mathrm{O}$, Kaya H, Gokdemir MT, et al. Acute myocardial infarction and coronary vasospasm associated with the ingestion of cayenne pepper pills in a 25 -year-old male. Int J Emerg Med 2012;5:5.

3 Singhal AB, Hajj-Ali RA, Topcuoglu MA, et al. Reversible cerebral vasoconstriction syndromes: analysis of 139 cases. Arch Neurol 2011;68:1005-12.

Copyright 2018 BMJ Publishing Group. All rights reserved. For permission to reuse any of this content visit http://group.bmj.com/group/rights-licensing/permissions.

BMJ Case Report Fellows may re-use this article for personal use and teaching without any further permission.

Become a Fellow of BMJ Case Reports today and you can:

- Submit as many cases as you like

- Enjoy fast sympathetic peer review and rapid publication of accepted articles

- Access all the published articles

Re-use any of the published material for personal use and teaching without further permission

For information on Institutional Fellowships contact consortiasales@bmjgroup.com

Visit casereports.bmj.com for more articles like this and to become a Fellow 